\title{
WORKPLACE SPIRITUALITY AND \\ WORK ENGAGEMENT AMONG HIGH SCHOOL TEACHERS IN BANDA ACEH
}

\author{
Eka Dian Aprilia, Oshan Katiara \\ Prodi Psikologi, Fakultas Kedokteran, Universitas Syiah Kuala \\ Jl. Tgk. Tanoh Abee, Kopelma Darussalam, Banda Aceh 23111, Indonesia \\ eka.aprilia@unsyiah.ac.id
}

\begin{abstract}
Work engagement is vivacious for teachers to improve and maintain the quality of education. One of the factors that can improve work engagement is workplace spirituality. The study aimed to determine the relationship between workplace spirituality and work engagement of High School teachers. This study used a quantitative method with a cluster random sampling technique and the sample size was based on Isaac and Michael table with a 5\% error level with 120 participants who work as civil servant High School teachers in Banda Aceh. The scales used in this study are an adaptation of Workplace Spirituality Scale developed by Milliman, Czaplewski, and Ferguson and adaptation of Utrecht Work Engagement Scale (UWES) by Schaufeli, Salanova, GonzalezRoma, and Bakker. The result of data analysis using the Pearson Product-Moment Correlation test showed a correlation coefficient of .397 with p-value $=.000(p<.05)$. The hypothesis was confirmed so it can be concluded that there was a significant positive correlation between workplace spirituality and work engagement of High School teachers. It means the higher the workplace spirituality of teachers, the higher the work engagement of teacher will be and vice versa. The results showed that the majority of workplace spirituality and work engagement of High School teachers in Banda Aceh classified into "high" category.
\end{abstract}

Keywords: workplace spirituality; work engagement; High School teachers

\begin{abstract}
Abstrak
Work engagement adalah hal yang penting bagi guru untuk meningkatkan dan mempertahankan kualitas pendidikan. Workplace spirituality merupakan salah satu variabel yang dapat meningkatkan workengagement. Penelitian ini bertujuan untuk mengetahui hubungan antara workplace spirituality dengan work engagement pada guru SMA. Penelitian ini menggunakan metode kuantitatif dengan teknik pengambilan sampel cluster random sampling dan jumlah sampelnya berpedoman pada tabel Isaac dan Michael dengan taraf kesalahan 5\% dengan jumlah 120 subjek yang berprofesi sebagai guru PNS di SMA Banda Aceh. Alat ukur yang digunakan dalam penelitian ini adalah adaptasi Skala Workplace Spirituality yang disusun dan dikembangkan oleh Milliman, Czaplewski dan Ferguson dan Skala adaptasi Utrecht Work Engagement Scale (UWES) yang disusun oleh Schaufeli, Salanova, Gonzalez-Roma, dan Bakker. Hasil analisa data menggunakan Pearson ProductMoment Correlation menunjukkan koefisien korelasi $(r)$ sebesar 0,397 dengan nilai $p=0,000(p<0,05)$. Hipotesis yang diajukan diterima sehingga dapat disimpulkan bahwa terdapat hubungan positif dan signifikan antara workplace spirituality dan work engagement pada guru SMA Banda Aceh. Hal ini menunjukkan semakin tinggi workplace spirituality maka semakin tinggi work engagement guru SMA Banda Aceh. Hasil penelitian juga menunjukkan bahwa mayoritas tingkat workplace spirituality dan work engagement pada guru SMA Banda Aceh tergolong dalam kategori tinggi.
\end{abstract}

Kata Kunci: workplace spirituality; work engagement; guru SMA Banda Aceh

\section{INTRODUCTION}

Indonesia is the fourth country with the most population in the world (detik.com, 2014). Therefore, good quality human resources are fundamental (Saharuddin \& Budiman, 2014).
One way to improve quality is through education and it's essential like the teacher (Man \& Hadi, 2013). Ramayulis (2013) expresses that the teacher is an individual who is responsible for guiding students to become human beings who humanize 
humans so that the central assignments are educating, teaching, guiding, directing, training, assessing and evaluating the students. Related to that, teachers become an essential factor in education. When it is not handled well then it will give an impact on the low of education quality and achievement (Srinalia, 2015).

The quality of education is generally associated with the level of achievement shown and considered imperative because it is very determining the pace of development in any country. Therefore, almost all countries in the world constantly attempt to improve the quality of education as an effort to improve the quality of life of the community (Lailatussaadah, 2015). The quality of education is largely determined by optimal teacher's performance (Indraswari \& Adiputra, 2015).

The presented of education quality in Aceh tends to modest, the basis is the inadequate teacher's quality affect their poor performance (Jaya, 2014). In 2013, Based on teachers' competency tests in Aceh, it has shown from 117,978 teachers, the quality was ranked $28^{\text {th }}$ nationally (Jaya, 2014), and decreased in 2015 to $32^{\text {nd }}$ on a national level (Bakri, 2016).

Teacher competence can be defined as mastery of knowledge, skills, values, and attitudes that are reflected in the habits of thinking and performing in carrying out the profession as a teacher (Astuti, 2017). Based on the ground, teachers in Aceh still have a low level of commitment and enthusiasm. It supported by Jaya's survey (2014) in several schools in Aceh in 2010-2014 which found that the level of teacher attendance at schools was relatively very low in intensity. Teachers who lack discipline are related to commitment, enthusiasm, and less passion to do their work (Mujiasih \& Ratnaningsih, 2012).

Teachers' optimal performance requires a feeling of satisfaction, enthusiasm, fully involved in their job (Srimulyani, Rustiyaningsih \& Kurniawati, 2016). Positive feelings and high enthusiasm for the job are defined as work engagement (Joushan, Syamsun, \& Kartika, 2015). Work engagement is an organization's way to stimulate employees to work at full capacity (Bakker \& Leiter, 2010). Thus, employees with a high level of work engagement can be indicated by getting fully involved, displaying optimal performance and tend to give more than what their job demands (Puspita, 2013).

Ram and Prabhakar (2011) stated that a high level of work engagement is obtained when employees decide to involve themselves, commit wholehearted, enthusiastic in doing the work they have and believe that their work made things better. Therefore, it can shape individual behavior that will provide positive input to colleagues and organizations and will endow with more time, attempt and initiative that can contribute to improving performance (Rachmawati, 2013).

Instead, Kompaso and Sridevi (2010) utter that disengaged employees will have a negative impact on the organization because they performing minimal, low level of productivity and show a high level of absenteeism.

Research conducted by Saks (2011) revealed that work engagement is related to workplace spirituality, where this is important for the employees' meaningfulness in the workplace as well as to maintain the level of individual work engagement. Workplace spirituality encourages employees to attain meaningful work and allows individuals to show their abilities and get satisfaction at work (Khan, Khan, \& Chaudhry, 2015). This form will lead a positive perspective on the organization; employees develop better work adjustments, encourage job satisfaction, be more committed, organizational well-being, and 
encourage the emergence of employees' work engagement (Altaf and Cloud, 2011).

Caracas (2010) suggests that workplace spirituality has an essential role in three points of view. First, come from the perspective of human resource management. It views spirituality can improve the welfare and quality of life of employees. In this perspective, spirituality can amplify morality, productivity, and organizational commitment. Conversely, the absence of spirituality in the workplace can make employees stressed, poor attendance, and physical and mental fatigue so that commitment to work is condensed. Gall, Charbonneau, and Florack (2011) argue that spiritual beliefs in relation to their transcendence can facilitate the creation of personal life values and the goals or life directions, which spiritual beliefs help individuals to understand every uncomfortable condition that must be borne or the suffering they endured.

The study from Dehaghi, Goodrazi, and Arazi (2012) concluded that by increasing the spirituality climate in the workplace, organizational commitment, individual and organizational performance can be improved. Every organization would expect its employees to have high organizational commitment because it will provide a positive influence on the organization (Mehran, 2017). Hence, if the school environment has high workplace spirituality, then it indicates that teachers will try to bring themselves to continue working as well as possible, so it will lead to individuals who have a work spirit in implementing their roles which are part of work engagement (Schaufeli, Salanova, Gonzalez-Romá \& Bakker, 2002). Finding meaning in work can improve work engagement and be engaged in working can improve one's performance. (Van Wingerden \& Van der Stoep, 2018).

Spirituality at work is an acknowledgment that employees have an inner life that nourishes by the existence of meaning in work carried out in a community (Saks, 2011). Organizations that encourage spirituality experiences will enhance organizational performance and profitability by empowering employees to show a variety of tasks and non-task related behaviors. This facilitates employees to become more committed to work and helps them to improve and progress the organization (Pradhan, Panigrahy \& Jena, 2015).

Karakas (2010) describes the role of spirituality to shape the value and meaning of work, and spirituality can form a sense of community attachment. In this case, the teacher performs his role in the school as an implementation of harmony between personal values with the organization's values in order for the work to become part of himself and life goals. The teacher is affected that work is an inseparable part of his life. In the sense of spirituality in the workplace makes employees fully concern, dedication, enthusiasm, creativity, integrity, performance, and increase productivity (Sungkit \& Meiyanto, 2015). Individuals' values can hold the teachers to overlook the meaningfulness of work in workspaces of spirituality (Liwun \& Prabowo, 2015). Notwithstanding, if the teacher put the meaning to his work, then it does not only transfer the knowledge but also to shape the students' character (Liwun \& Prabowo, 2015).

Workplace spirituality denotes an essential aspect for the organization which develops employees' effectiveness in working because employees who see work as a tool to increase the spirituality will put more effort compared to employees who see work as earn the money. its usefulness can be seen in the influence of positive ethics that can create effectiveness and efficiency in the organization

This will enlarge work engagement since employees work not because of pressure and will tend to be enthusiastic in finishing their 
job (Puspita, 2013; Joushan, Syamsun \& Kartika, 2015).

\section{METHOD}

In this quantitative correlational study, from 1,322 high school teachers which consist of 1,079 civil servants and 243 non-civil servants in Banda Aceh, 120 teachers have participated. The inclusion criteria were as follows: (a) having status as civil servants, (b) having more than five work years' experiences as a teacher, (c) having active status/ not on leave, (d) willing to participate in the study, (e) teaching at High School, (f) the High School doesn't apply for boarding system.

Data were collected using the questionnaire, Workplace Spirituality Scale developed by Milliman, Czaplewski, and Ferguson (2003) within each dimension has a reliability coefficient .88, .91, and .94 (Milliman, Czaplewski\& Ferguson, 2003). The blueprint of the Workplace Spirituality Scale was shown at Table 1.

Table 1.

Blueprint Workplace Spirituality Scale

\begin{tabular}{lcc}
\hline \multicolumn{1}{c}{ Aspect } & Item & Total \\
\hline Meaningful work & $1,2,7,8,13,14$ & 6 \\
Sense of Community & $3,4,9,10$, & 7 \\
Alignment with organizational & $15,16,19$ & \\
values & $5,6,11,12,17$, & 8 \\
\hline \multicolumn{1}{c}{ Total } & $18,20,21$ & \\
\hline
\end{tabular}

Work Engagement Scale developed according to the guidance of The Utrecht Work Engagement Scale Schaufeli and Bakker (2003) based on the theory of Schaufeli, Salanova, Gonzalez-Romá, and Bakker (2002) has a reliability coefficient 0.93 (Schaufeli \& Bakker, 2003). The blueprint of the Work Engagement Scale as shown in Table 2.

Table 2.

Blueprint Utrecht Work Engagement Scale (UWES)

\begin{tabular}{ccc}
\hline Aspect & Item & Total \\
\hline Vigor & $1,4,8,12,15,17$ & 6 \\
Dedication & $2,5,7,10,13$ & 5 \\
Absorption & $3,6,9,11,14,16$ & 6 \\
\hline Total & & 17 \\
\hline
\end{tabular}

Sampling in this study was conducted using a non-probability sampling method with a cluster random sampling technique. From 19 public high schools spread across several sub-districts in Banda Aceh, 4 high schools were selected as the respondents.
Considering the normal distribution of the data, the Pearson Product-Moment Correlation was used.

\section{RESULTS AND DISCUSSION}

The results of the analysis in this study indicate the significance value is $p=.000$ less than $.05(p<.05)$. Based on the result shown in Table 3, the hypothesis is accepted. There is a relationship between workplace spirituality with work engagement among High School teachers in Banda Aceh. The results of the study also showed a correlation coefficient $r=.397$ which was a positive correlation, which means there was a positive relationship between workplace spirituality and work management. The higher the level of workplace spirituality, the higher the level of work management of Banda Aceh High School teachers. Specifically, $96.7 \%$ of subjects had a high level of workplace spirituality and $61.67 \%$ of subjects had a high level of work engagement. 
Table 3.

Hypothesis Testing

\begin{tabular}{ccccr}
\hline Variable & $p$ & $\mathrm{R}$ & $\mathrm{R}$ Square & \\
\hline Workplace Spirituality and Work Engagement & $.000<.05$ & .397 & .158 & Accepted \\
\hline
\end{tabular}

The study results are in line with the previous research that shown workplace spirituality correlated with work engagement. Followed Sacks (2011), the results have shown connectivity and similarity. Both, workplace spirituality and work engagement have a feeling of completeness and wholeness. Theoretically, Milliman, Czaplewski, and Ferguson (2003) stated that almost all definitions of spirituality involve wholeness, which fully involving themselves in their performance when carrying out roles in the workplace. Work engagement is a personal thing. Each individual will have a different level of management according to the trait level or perspective (Bakker \& Leiter, 2010). The significance of the employees who has work engagement when working can be indicated by their performance, since they will passionate and dedicated with their work, such as teachers with personal achievement both at the regional and national levels, also able to make their students gain achievement (Schaufeli, Salanova, Gonzalez-Romá, \& Bakker, 2002). Thus, it can be said that when teacher fully involves investing their selves cognitively, physically and emotionally then they have work engagement (Kahn, 1990; Rich, Lepine, \& Crawford, 2010).

Consequently, when individuals involve themselves in carrying out their roles, it will impact the wholeness of work performance, increase work engagement, and end with positive results.

Work engagement is unalike from workaholics, engaged employees do not work hard because of strong and unbearable inner motives, but because their work is perceived as something enjoyable (Gorgievski, Bakker \& Schaufeli in Bakker, 2011). In a study conducted by Torabi and
Javadi (2013), it specified there was a positive relationship between spirituality and work engagement of nurses. In contrast, engagement can build psychological conditions intended to measure how much employees are engaged in their work. Spiritual workplaces in teachers are characterized by the existence of meaning and deep goals of work that can be seen from teachers who enjoy work, feel alive because of work and get personal meaning and purpose (Milliman, Czaplewski, \& Ferguson, 2003). By emerging this, teachers always deliver honesty and trust in the learning process, so that education and evaluation processes are achieved. It ended purposively with teachers' work engagement, lead to creativity and productivity. Teachers with work engagement will be enthusiastic and happy to accept work as a whole that spurs to achieve various achievements (Schaufeli, Salanova, Gonzalez-Romá, \& Bakker, 2002; Duchon \& Plowman, 2005). Therefore, workspaces of spirituality can make teachers better in carrying out existing goals so as to increase productivity as well, which is a bounce effect to work management (Jurkiewicz \& Giacalone 2004; Harter, Schmidt \& Hayes, 2002). This can be seen in students who have the competitiveness ability, from graduates who are able to compete in a number of favorite universities in Indonesia (Schaufeli, Salanova, GonzalezRomá\& Bakker, 2002; Rachmawati, 2013; Hastings \& Agrawal, 2015).

Meanwhile, a key component of workspaces spirituality is about the importance of connections, explicitly having strong relationships with others (Ashmos \& Duchon, 2000), such as teachers who support one another, the feeling of being connected with colleagues and also connected with shared goals (Milliman, Czaplewski, \& 
Ferguson, 2003). Social interaction can be translated as a reciprocal relationship between individuals, individuals with groups or a group with another group which in that relationship can transform, influence, improve between one individual and another individual (Mahmudah, 2011).

Based on our observations, while at school, the participants often interact by gathering in small groups or large groups to deliberate or support each other to solve problems. It is an indication that local culture has influenced such as solidarity and consensus agreement values. When teachers have social relationships with others, it will increase work engagement because they experience positive interpersonal interactions with coworkers (Kahn, 1990).

In addition to interactions that make teachers feel connected to their colleagues, workplace spirituality also encourages teachers to experience strong feelings between personal values and mission and goals of school (Milliman, Czaplewski, \& Ferguson, 2003). The impact of the unity of the teacher's vision and mission with the school will bring improvement and change. Hence, it will provide knowledge sharing, mutual trust, open communication with each other, develop keen, pleasant and ethics of working atmosphere in school (Zagloel, Yadrifil, \& Laricha, 2008). This is evident from the feeling of being connected with the goals of the school and mutually receiving the school's attention towards them. School support is one of the positive antecedent forms of work engagement. It will bring good influence if it is considered as an action taken by the organization voluntarily in the interests of the teachers (Man \& Hadi, 2013). This renders teachers' positive feelings towards the school that make themselves feel part of the community and make them engaged in work and school environment. Thus, teachers' workplace spirituality can encourage them to engage when working, which can be seen from their quality and work discipline as a form of individual values congruence with the school mission and goals (Schaufeli, Salanova, GonzalezRomá, \& Bakker, 2002; Duchon \& Plowman, 2005).

The results of this study showed as many as 96.7\% of Banda Aceh High School teachers had a high level of workplace spirituality. Individuals with high workplace spirituality have better discipline, enthusiasm, problem solvers and are more concerned with the quality of work than individuals who have low-level workplace spirituality because they will be more often present, mindful and more focused on existing tasks (Petchsawanga \& Duchon, 2012). It found on the participants where they teach on time, using a variety of teaching media and have high expectations about their students successfully passing the selection in University. In the end, teachers will feel a meaningful life, experienced work well-being, and produce happiness and full presence in work (Hakim \& Azlimin, 2015).

The descriptive data have shown work engagement among high school teachers in Banda Aceh in the high-level category $(62.67 \%)$. Teachers with a high level of work engagement posited robust commitment to their work which is characterized by high involvement in efforts to develop the organization, in this case, the school where they work (Schaufeli, Salanova, GonzalezRoma, \& Bakker, 2002). From our observation and interview, it is known that teachers eager to really want to create excellent students and produce potential in various ways, not merely but also, but their students can compete in higher education and the industrial world.

Workplace spirituality had a $15.8 \%$ contribution to work engagement. Meanwhile, the remaining $84.2 \%$ can be influenced by other factors. Further, these factors could affect work engagement include job demand and job resources such as the physical, social, organizational, salary, career opportunities, and supervisors' and coworkers' support (Schaufeli \& Bakker, 
2003). Job demand has a vital role in defining employees' work engagement, employees who perceive the workload as a challenge for him and do not consider the existence of physical and psychological fatigue in completing work tends to increase work engagement (Schaufeli, Salanova, Gonzalez-Romá, \& Bakker, 2002). Contrarywise, employees who consider work as a burden will experience difficulties and burnout, such as teachers who must up-todate with the development of curriculum and the same time trying to fulfill teaching obligations in order to obtain certification which is a challenging situation.

In addition to job demand, personal resources also encourage work management. Ayu, Maarif, and Sukmawati (2015) detailed that if an individual has great resilience and confidence about his ability to control, manipulate, and impact the environment in accordance with his desires and capacities, it will hearten increased work engagement. While individuals who consider work as demand will see the surrounding environment as a threat and subsequently will have difficulty displaying optimal performance.

Overall, it can be said the individual is aware of feeling content with the job, he will achieve the meaning and personal goals as a teacher. So that the majority of teachers have high workplace spirituality. In addition, the feeling of being connected with colleagues, having a supporting system, and shared goals are also expected to be able to maintain a high level of teacher involvement and cognitively, affective, and behavior attached in their work.

Furthermore, we are hopes that the school will emphasize that the main task of teachers in schools is to educate, teach, guide, direct, train, assess, and evaluate students. Teachers who perform well will raise workplace spirituality, so as to they can encourage themselves to become part of their community and attached to the work and the school environment. Maintaining a sense of bonding with schools is very important so that there is no disparity between fellow teachers. Schools can also always facilitate teachers to be in compliance with the organization's vision and mission so that harmony is created to achieve common goals. Thus, the teachers will focus on their work and assume that as a conscience which can provide meaningful work that becomes an inseparable part of their life.

It is expected that schools will be able to maintain the support that has been given well to their teachers. School support for teachers is paramount in order to increase the enthusiasm and commitment of teachers to continuously work hard and perseverance when facing work difficulties. Schools also need to give credit to outstanding teachers and role model teachers with the aim of receiving full involvement. Also, the school must open to accept the creative and innovative ideas given by the teacher so that the emergence of feelings of pleasure at work and have an impact on a better education process thus the teacher does not only concentrate on one learning method.

\section{CONCLUSION}

This study aims to determine the relationship between workplace spirituality and work engagement among High School teachers in Banda Aceh. The research revealed that workplace spirituality has a positive and significant relationship with work engagement in Banda Aceh High School teachers. The results also show that the higher the level of workplace spirituality, the higher the level of work engagement or the lower the level of workplace spirituality, the higher the level of work engagement. Workplace spirituality contributed $15.8 \%$ to work engagement, while $84.2 \%$ was influenced by other factors. In this sense, the majority of Banda Aceh High School teachers had a high level of workplace spirituality and work engagement. Future studies should focus on other variables that 
might affect workplace spirituality and employee management. However, the literature and research that addresses these two issues are also narrow, especially in Indonesia. We, therefore, suggest that further studies are expected to develop research on workplace spirituality and employee management to add to the literature to strengthen the results of previous research, especially research involving other variables such as length of work, as well as research that develops analytical techniques, for example using factor analysis on each aspect. Furthermore, research will also be better if using various work backgrounds such as contract teachers, permanent employees, contract employees, bank employees, nurses, and lecturers.

\section{REFERENCE}

Altaf, A., \&Awan, M.A (2011). Moderating affect of workplace spirituality on the relationship of job over load and job satisfaction. Journal of Business Ethics, 104, 93-99. doi: 10.1007/s10551-011-0891-0

Ashmos, D. P., \& Duchon, D. (2000). Spirituality at work: A conceptualization and measure. Journal of Management Inquiry, 9, 133-145. $10.1177 / 105649260092008$

Astuti, S. (2017). Supervisi akademik untuk meningkatkan kompetensi guru di SD Laboratorium UKSW. Scholaria, 7, 49-59.

Ayu, D. R., Maarif, S., \& Sukmawati, A. (2015). Pengaruh job demands, job resources dan personal resources terhadap work engagement. Jurnal Aplikasi Bisnis dan Manajemen (JABM), 1, 12-22.

Bakker, A.B., \& Leiter, M.P. (2010). Where to go from here: Integration and future research on work engagement.
In Bakker, A. B., \& Leiter, M. P (Eds), Employee engagement: A handbook of essential theory and research (pp. 181-196). New York, NY: Psychology Press.

Bakker, A.B. (2011). An evidence-based model of work engagement. Current Directions in Psychological Science, 20. doi:10.1177/0963721411414534

Bakri, B. (2016, 19 Juli). Anggaran tertinggi, kualitas terendah. Serambi Indonesia. Diunduh dari http://aceh. tribunnews.com/2016/07/19/anggaran -tertinggi-kualitas-terendah

Dehaghi, M. R., Goodarzi, M., \& Arazi, Z. K. (2012). The effect of spiritual values on employees' organizational commitment and its models. Procedia - Social and Behavioral Sciences, 62, $159-166$.

Duchon, D. \& Plowman, D. A. (2005) Nurturing the spirit at work: Impact on work unit performance. Leadership Quarterly, 16(5), 807833.

doi:10.1016/j.leaqua.2005.07.008.

Gall, T.L., Charbonneau, C., \& Florack, P. (2011). The relationship between religious/spiritual factors and perceived growth following a diagnosis of breast cancer. Psychology \& Health, 26, 287-305. doi:10.1080/08870440903411013

Hakim, A., \& Azlimin, A. (2015). Model peningkatan komitmen sumber daya manusia berbasis spiritual leadership dan spiritual survival serta workplace spirituality dengan moderating individual spirituality. Conference in Business, Accounting and Management, 2(1), 344-356.

Harter, J. K., Schmidt, F. L., Hayes, \& Theodore, L. (2002). Business-unitlevel relationship between employee 
satisfaction, employee engagement, and business outcomes: A metaanalysis. Journal of Applied Psychology, $\quad 87, \quad 268-279$. doi:10.1037//0021-9010.87.2.268

Hastings, M., \& Agrawal, S. (2015, 9 Januari). Lack of teacher engagement linked to 2.3 million missed workdays. Diakses melalui http://www.gallup.com /poll/180455/lack-teacherengagement-linked-million-missedworkdays. aspx

Indraswari, P. G., \& Adiputra, I. N. (2015). Perbedaan skor work engagement guru SMP Negeri di Kecamatan Denpasar Utara pada kelompok masa kerja 1-4 tahun, 5-19 tahun, dan lebih dari 20 tahun. Jurnal Ergonomi Indonesia, 1, 37-50.

Jaya, S. O. (2014, 25 November). Guru dan etos kerjanya. Serambi Indonesia. Diunduh dari http://aceh.tribunnews.com/2014/11/2 5/guru-dan-etos-kerjanya

Joushan, S. A., Syamsun, M., \& Kartika, L. (2015). Pengaruh budaya organisasi dan employee engagement terhadap kinerja karyawan pada PT PLN (Persero) Area Bekasi. Jurnal Aplikasi Manajemen (JAM), bakkaer, 4, 697-703.

Jurkiewicz, C. L., \& Giacalone, R. A. (2004). A values framework for measuring the impact of workplace spirituality on organizational performance. Journal of Business Ethics, 49, 129. 142.

doi:10.1023/B:BUSI.0000015843.221 95.b9

Kahn, W. A. (1990). Psychological conditions of personal engagement and disengagement at work. Academy of Management Journal, 33,692-724. doi: $10.5465 / 256287$
Karakas, F. (2010). Spirituality and performance in organizations: A literature review. Journal of Business Ethics, 94, 89-106. doi:10.1007/s10551-009-0251-5

Khan, K. E., Khan, S. E., \& Chaudhry, A., G. (2015). Impact of servant leadership on workplace spirituality: Moderating role of involvement culture. Pakistan Journal of Science, 67(1),109-113.

Kompaso, S. M., \& Sridevi, M. S. (2010). Employee engagement: The key to improving performance.

International Journal Business and Management, 5, 89-96. doi: $\underline{10.5539 / i j b m . v 5 n 12 p 89}$

Lailatussaadah. (2015). Upaya peningkatan kinerja guru. Intelektualita, 3, 15-25.

Liwun, S. B., \& Prabowo, H. (2015). Pengaruh keterlibatan kerja dan spiritualitas kerja terhadap komitmen organisasi. Jurnal Psikologi, 8, 32-40.

Man, G. S., \& Hadi, C. (2013). Hubungan antara perceived organizational support dengan work engagement pada guru SMA swasta di Surabaya. Jurnal Psikologi Industri dan Organisasi, 2, 90-99.

Mehran, Z. (2017). The effect of spirituality in the workplace on organizational commitment and organizational citizenship behavior. International Journal Human Capital Urban Manage, 2, 219-228. doi:10.22034/ijhcum.2017.02.03.006

Milliman, J., Czaplewski, A. J., \& Ferguson, J. (2003). Workplace spirituality and employee work attitudes: An exploratory empirical assessment. Journal of Organizational Change Management, $\quad 16, \quad 426-447$. doi:10.1108/09534810310484172

Mujiasih, E., \& Ratnaningsih, I. Z. (2012). 
Meningkatkan work engagement melalui gaya kepemimpinan transformasional dan budaya organisasi. Proceedings Unisbank Semarang. Diakses melalui http://eprints.unisbank.ac.id/464/

Negara dengan Penduduk Terbanyak di Dunia, RI Masuk 4 Besar. (2014, 6 Maret). Detik Finance. Diunduh darihttp://finance.detik.com/ekonomibi snis/2517461/negara-dengan-pendu duk-terbanyak-di-dunia-ri-masuk-4besar

Petchsawanga, P., \& Duchon, D. (2012). Workplace spirituality, meditation, and work performance. Journal of Management, Spirituality \& Religion, 9, 189-208. doi:10.1080/14766086.2012.688623

Pradhan, R. A., Panigrahy, N. P., \& Jena, L. K. (2015). Workplace spirituality and employee performance: The mediating role of organisation citizenship behaviour. Journal of Contemporary Psychological Research, 2(1), 40-48. doi:10.1177/0971890716670721

Puspita, M. D. (2013). Hubungan antara dukungan sosial dan makna kerja sebagai panggilan (calling) dengan keterikatan kerja. Calyptra: Jurnal Ilmiah Mahasiswa Universitas Surabaya, 1, np.

Rachmawati, M. (2013). Employee engagement sebagai kunci meningkatkan kinerja karyawan. Among Makarti, 6, 52-65.

Ramayulis. (2013). Profesi \& etika keguruan. Jakarta: Kalam Mulia.

Ram, P., \& Prabhakar, G. V. (2011). The role of employee engagement in work-related outcomes. Interdisciplinary Journal of Research in Business, 1, 47-61.
Rich, B. L., Lepine, J. A., \& Crawford, E. R. (2010). Job engagement: Antecedents and effects of job performance. Academy of Management Journal, 53, 617-635. doi:10.5465/amj.2010.51468988

Saharuddin, S., \& Budiman, B. (2014). Pengaruh kualitas sumber daya manusia dalam meningkatkan kinerja tim pengelola kegiatan program nasional pemberdayaan masyarakat mandiri pedesaan (TpkPnpm-Mp) Pnpm-Mp di Kecamatan Masamba Kabupaten Luwu Utara. Jurnal Manajemen, 1, 58-72.

Saks, A. M. (2011). Workplace spirituality and employee engagement. Journal of Management, Spirituality \& Religion, 8, 317-340. doi:10.1080/14766086.2011.630170

Schaufeli, W. B., Salanova, M., GonzalezRomá, V., \& Bakker, A. B. (2002). The measurement of engagement and burnout: A confirmative analytic approach. Journal of Happiness Studies, 3, 71-92. doi:10.1023/A:1015630930326

Schaufeli, W. B, \&Bakker, A. B. (2003). Utrecht work engagement scale (UWES), preliminary manual version 1. Belanda: UtrechtUniversity.

Mahmudah, S. (2011). Psikologi sosial: Teori dan model penelitian. Malang: UIN-Maliki Press.

Srimulyani, V. A., Rustiyaningsih, S., \& Kurniawati, D. (2016). Dampak integrative leadership dan employee engagement terhadap perilaku extrarole. Jurnal Manajemen Teknologi, $15,36-50$.

Srinalia, S. (2015). Faktor-faktor penyebab rendahnya kinerja guru dan korelasinya terhadap pembinaan siswa: Studi kasus di SMAN 1 Darul 
Imarah Aceh Besar. Jurnal Ilmiah DIDAKTIKA, 15, 193-207.

Sungkit, F. N., \& Meiyanto, I. J. K. S. (2015). Pengaruh job enrichment terhadap employee engagement melalui psychological meaningfulness sebagai mediator. Gadjah Mada Journal of Psychology, 1 , 61-73. doi:10.22146/gamajop.7354

Torabi, M., \& Javadi, S. (2013). Studying the impact of spiritual intelligence on job engagement. International Journal of Economy, Management and Social Sciences, 2, 752-756.
Van Wingerden, J., \& Van der Stoep, J. (2018). The motivational potential of meaningful work: Relationships with strengths use, work engagement, and performance. PLOS ONE, 13, 111.doi:

10.1371/journal.pone.0197599.

Zagloel, T. Y., Yadrifil., \& Laricha, L. (2008). Perencanaan strategi dalam upaya menyelaraskan tujuan organisasi dan tujuan karyawan dengan pendekatan total performances core card (studi kasus departemen internal audit perusahaan minyak dan gas bumi). Jurnal Teknik Industri, 10, 138-150. 